\title{
Persepsi Guru Bahasa Indonesia SMP Negeri Se-Kecamatan Brebes Terhadap Penilaian Autentik untuk Keterampilan Membaca pada Kurikulum 2013
}

\author{
Perceptions of Bahasa Indonesia Teachers at State Junior High Schools in Brebes District \\ towards Authentic Assessment of Reading Skills in the Curriculum 2013
}

\author{
${ }^{1 *}$ Ratih Nur Eva Sari, ${ }^{2}$ Sukirno \\ ${ }^{1,2)}$ Program Studi Magister Pendidikan Bahasa dan Sastra Indonesia \\ Universitas Muhammadiyah Purwokerto \\ Jl. KH. Ahmad Dahlan PO BOX 202 Purwokerto 53182 \\ *email: ratihnurevasari@gmail.com, sukirnopwt56@gmail.com
}

Histori Artikel:

Diajukan:

$07 / 01 / 2021$

Diterima:

09/07/2021

Diterbitkan:

$13 / 07 / 2021$

\section{ABSTRAK}

Penelitian ini bertujuan untuk mendeskripsikan persepsi, guru Bahasa Indonesia SMP Negeri se-kecamatan Brebes terhadap penilaian autentik dalam keterampilan membaca dilihat dari segi penyerapan, pemahaman, dan penilaiannya. Penelitian ini merupakan jenis penelitian kuantitatif dengan menggunakan pendekatan deskriptif. Metode yang digunakan dalam penelitian ini yaitu statistik deskriptif Populasi untuk penelitian ini adalah seluruh guru Bahasa Indonesia di SMP Negeri se-Kecamatan Brebes dengan jumlah 8 SMP Negeri. Kemudian dari populasi tersebut diambil sampel 20 guru. Teknik pengumpulan data menggunakan angketatau kuesioner online yang berjumlah 50 soal. Teknik analisis data menggunakan teknik statistik deskriptif dalam bentuk deskriptif dan distribusi frekuensi. Berdasarkan hasil analisis data guru Bahasa Indonesia di SMP Negeri se-Kecamatan Brebes diketahui Sebanyak 15\% memiliki persepsi yang tinggi terhadap penilaian autentik dalam pembelajaran membaca. Sebanyak 75\% lainnya memiliki persepsi yang sedang terhadap penilaian autentik dan dapat diketahui pula sebanyak 10\% lainnya memiliki persepsi rendah terhadap penilaian autentik dalam pembelajaran membaca pada mata pelajaran Bahasa Indonesia. Persepsi guru Bahasa Indonesia di SMP Negeri se-Kecamatan Brebes terhadap penilaian autentik dalam pembelajaran Bahasa Indonesia dapat dilihat setidaknya dari tiga indikator yaitu indikator penyerapan, pemahaman dan penilaian. Setelah dianalisis dan dilakukan pengkategorian, didapat hasil bahwa sebanyak $15 \%$ guru memiliki penyerapan yang tinggi, 70\% guru memiliki penyerapan sedang, $15 \%$ guru memiliki penyerapan rendah terhadap informasi mengenai penilaian autentik, sebanyak $15 \%$ guru memiliki pemahaman yang tinggi $65 \%$ guru memiliki pemahaman sedang, 20\%guru memiliki pemahaman rendah terhadap penilaian autentik, sementarasebanyak $20 \%$ guru memiliki penilaian yang tinggi $70 \%$ guru memiliki penilaian sedang, 10\%guru memiliki penilaian rendah terhadap penilaian autentik.Semua hasil rata-rata indikator tersebut berada pada kategori baik. Oleh karena itu, dapat diambil kesimpulan bahwa persepsi guru Bahasa Indonesia terhadap penilaian autentik dalam keterampilan membaca di SMP Negeri se-Kecamatan Brebes adalah baik.

Kata kunci: Persepsi; Penilaian Autentik; Membaca 
Ratih Nur Eva Sari, Sukirno

Persepsi Guru Bahasa Indonesia SMP Negeri Se-Kecamatan Brebes Terhadap Penilaian Autentik untuk

Keterampilan Membaca pada Kurikulum 2013

\begin{abstract}
This study aims to describe the perception of Indonesian language teachers at State Junior High Schools in the district of Brebes towards authentic assessments in reading skills in terms of absorption, understanding, and assessment. This research is a type of quantitative research using a descriptive approach. The method used in this study is descriptive statistics. The population for this study is all Indonesian language teachers in State Junior High Schools in Brebes District with a total of 8 State Junior High Schools. Then from the population a sample of 20 teachers was taken. Data collection techniques using online questionnaires or questionnaires totaling 50 questions. The data analysis technique used descriptive statistical techniques in the form of descriptive and frequency distribution. Based on the results of data analysis of Indonesian language teachers at state junior high schools throughout the Brebes sub-district, it was found that $15 \%$ had a high perception of authentic assessment in learning to read. Another 75\% have a moderate perception of authentic assessment and it can be seen that another $10 \%$ have a low perception of authentic assessment in learning to read in Indonesian subjects. The perception of Indonesian language teachers in public junior high schools throughout the Brebes sub-district on authentic assessments in learning Indonesian can be seen from at least three indicators, namely absorption, understanding and assessment indicators. After analyzing and categorizing, it was found that $15 \%$ of teachers had high absorption, 70\% of teachers had moderate absorption, 15\% of teachers had low absorption of information about authentic assessment, 15\% of teachers had high understanding $65 \%$ of teachers had understanding moderate, $20 \%$ of teachers have a low understanding of authentic assessment, while as many as $20 \%$ of teachers have a high assessment of $70 \%$ of teachers have a moderate assessment, $10 \%$ of teachers have a low assessment of authentic assessment. All the average results of these indicators are in the good category. Therefore, it can be concluded that the perception of Indonesian language teachers towards authentic assessment of reading skills in State Junior High Schools in Brebes District is good.
\end{abstract}

Keywords: Perception; Authentic Assessment; Reading

\section{PENDAHULUAN}

Kurikulum 2013 menjelaskan bahwa bahasa Indonesia merupakan salah satu mata pelajaran di sekolah yang dipertahankan keberadaannya. Keberadaan bahasa Indonesia dianggap sebagai bahasa pengantar dalam menyampaikan suatu pengetahuan. Oleh karena itu, mata pelajaran bahasa Indonesia harus berada di depan semua mata pelajaran lain untuk dikuasai oleh peserta didik agar peserta didik dapat menguasai informasi, konsep maupun substansi dari pelajaran yang lainnya dengan lebih baik.

Membaca merupakan salah satu cara manusia untuk belajar akan segala hal penting yang berguna bagi kehidupan. Dari membaca seseorang akan mendapat banyak pengetahuan baru, keterampilan, dan kecakapan hidup. Membaca memungkinkan seseorang menemukan ide-ide atau inspirasi tentang berbagai pengetahuan serta pengalamannya.Membaca adalah suatu keterampilan. Jika sudah memilikinya, lambat laun menjadi perilaku keseharian. Keterampilan membaca sebagai salah satu kerampilan berbahasa merupakan keteram- pilan pokok yang terus menerus diperlukan, keterampilan membaca mempunyai peran penting dalam kehidupan manusia.

Penilaian merupakan bagian yang tidak terpisahkan dari pembelajaran secara keseluruhan. Kedudukan penilaian dalam desain penyelenggaraan pembelajaran adalah sebagai bagian dari rangkaian dari tigakomponen pokok penyelenggaraan, yaitu tujuan pembelajaran, kegiatan pembelajaran, dan enilaian hasil pembelajaran (Djiwandono, 2011:2). Kegiatan pembelajaran dirancang untuk mmemenuhi tujuan pembelajaran yang harus dicapai. Penilaian diperlukan untuk mengetahui tingkat keberhasilan dan ketercapaian tujuan pembelajaran. Penilaian juga digunakan sebagai uupan balik bagi proses pembelajaran iitu sendiri. Tujuannya adalah agar dapat dilakukan tindakan-tindakan perbaikan terhadap proses pembelajaran. Salah satu sifat penilaian yang baik adalah berkelanjutan, sehingga perbaikan dalam proses pembelajaran dapat dilakukan secara terus menerus.

Evaluasi hasil belajar peserta didik dilakukan oleh pendidik untuk memantau proses kemajuan, dan perbaikan hasil belajar peserta didik secara berkesinambungan (UU 
No. 20 Tahun 2003 tentang sistem pendidikan nasional pasal 58). Berdasarkan pernyataan tersebut, pentng bagi guru untuk mengetahui, memahami, dan mampu elaksanakan proses penilaian yang baik sesuai dengan kurikulum yang berlaku. Sejak kurikulum berbasis kompetensi (KBK) berlaku pada tahun 2004 dikenal adanya standar kompetensi, kompeensi dasar, dan indikator yang menunjukkan seberapa jauh tingkat pencapaian peserta didik terhadap materi yang dituntut dalam kurikulum. Untuk mengetahui pencapaian tersebut, penilaian tidak hanya dilakukan untuk mengukur hasil pembelajaran saja, tetapi juga menilai proses pembelajaran yang berlangsung di kelas. Oleh karena itu, guru sebagai seorang pendidik seharusnya tidak hanya mengukur peserta didik dari hasil belajanya, tetapi juga berdasarkan poses belajar yang dilalui peserta didik.

Sistem penilaian yang akrab digunakan di Indonesia adalah penilaian tradisional dengan menggunakan tes objektif. Penilaian tradisional lebih tepat digunakan untuk menggukur produk atau hasil belajar. Proses pemblajaran yang diilalui tidak dapat diukur dengan penilaian tradisional. Penggunaan penilaian tradisional juga penting untuk mengukur tingkat pemahaman peserta didik. Akan tetapi, penilaian tradisional dengan menggunakan tes objektif tidak dapat mengkur kompetensi peserta didik secara keseluruhan. Selain itu, penggunaan tes objektif dalam penilaian memiiliki kelemahan, salah satunya adalah memungkinkan faktor keberuntungan peserta didik dalam memilih jawaban.

Semenjak berlakunya kurikulum tingkat satuan pendidikan (KTSP) pada tahun 2006, pendekatan pembelajaran yang digunakan adalah pembelajaran kontekstual (ContextualTeaching and Learning). Pembelajaran kontekstual berusaha mempertemukan hal-hal yang dibelajarkan di sekolah dan hal-hal yang secara nyata ada dan dibutuhkan dalam kehidupan nyata (Nurgiyantoro, 2011:1). Oleh karena itu, dibutuhkan penilaian yang sesuai untuk mengetahui pencapaian tujuan dalam pembelajaran kontekstual tersebut.

Penilaian autentik atau yang biasa disebut penilaianautentik merupakan bentuk penilaian yang meminta peserta didik untuk menunjukkann kinerja dalam konteks dunia nyata yang menuunjukkan aplikasi bermakna dari penerapan pengetahuan dan keterampilan (Muelleer, 2013). Berdasarkan pengertian tersebut, penilaian autentik merupakan penilaian yang sesuai dengan tuntutan pembelajaran kontekstual. Penilaian autentik tidak hanya diigunakan untuk menilai hasil belajar peserta didik, tetapi juga proses pembelajaran yang dilakukan. Melalui penerapan penilaian autentik dalam pembelajaran, seluruh aktivitas peserta didik dapat dketahui keefektifannya dalam mendukung ketercapaian tujuan pembelajaran. Selain itu, implementasi penilaian autentik juga diyakini dapat digunakan untuk mengukur perkembangan karakter peserta didik (Abidin, 2012:249).

Tujuan penilaian autentik adalah untuk mengukur berbagai keterampilan dalam berbagai konteks yangg mencerminkan situasi di dunia nyata dimana keteramplan-keterampilan tersebut digunakan (Nurgiyantoro, 2011:23). Penilaian autentik jga dapat digunakan untuk menjamin informasi yyang sebenar-benarnya tentang kemampuan atau kompetensi peserta didik. Mueller (2013) menyebutkan bahwa penilaian autentik perlu dilakukan karena beberapa hal, yaitu (1) peniaian autentik merupakan penilaian secara langsung terhadap kemampuan dan kompetensi peserta didik, (2) penilaian autentik memberikan kesempatan bagi peserta didik untuk mengkontruksikan hasil pembelajaran, (3) penilaian autentik mengintegrasikan kegiatan belajar, mengajar, dan penilaian, dan (4) penilaian autentik memberikan kesempatan kepada peserta didik untuk mendemonstrasikan kemampuannya yang beragam.

Pendekatan pembelajaran konteksual diterapkan pada semua mata pelaaran tttak terkecuali mata pelajaran bahasa indonesia. Tujuan pembelajaran bahasa indonesia $d$ sekolah menengah adalah peserta didik mampu berkomunikasi dengan baik melalui membaca. Oleh karena itu, penilaan yang dilakukan harus mengukur kinerja keterampiila membaca tersebuut, bukan hana pemahaman pengetahuan peserta didik terhadap bahasa. Penilaan yang tepat digunakan untuk meila kinerja berbahasa secaa 
Ratih Nur Eva Sari, Sukirno

Persepsi Guru Bahasa Indonesia SMP Negeri Se-Kecamatan Brebes Terhadap Penilaian Autentik untuk Keterampilan Membaca pada Kurikulum 2013

nyata adalah penilaian autentik. Penilaian autentik mengutamakan penilaian pada kinerja berbahasa sebagaimana dalam komunikasi sehari-hari ddan bukan hanya penilaian pengetahuan bahasa.

Peniilaian autentik merupakan penilaian yang disarankan sejak berlakunya KBK dan gencar dibicarakan pada penerapan KTSP. Seharusnya, penilaiian autentik bukan lagi penilaian yang asing bagi guru di indonesia. Bahkan, dalam kurikulum 2013 penilaian autentik lebih ditekankan penggunaannya daripada penilaian tradisional. Idealnya, penilaian autentik sudah diterapkan dengan baik di sekolah-sekolah terutama yang telah menggunakan kurikulum 2013.

Peniaian pembelajaran tidak terlepas dari peran pendidik, dalam hal ini guru Bahasa Indonesia. Guru memiliki kebebasan dalam menentukan teknik penilaian yang digunakan. Oleh karenanya, penulis tertarik untuk mengetahui bagaimana persepsi guru Bahasa Indonesia SMP se-Kecamatan Brebes terhadap penilaian autentikdalam keterampilan membaca padakurikulum 2013. Penulis memilih guru-guru di SMP kecamatan Brebes sebagai target populasi karena wilayah yang relati dekat dengan kediaman penulis. Untuk menjawab pertanyaan di atas dilakukan penelitian untuk mengetahui bagaimana persepsi guru Bahasa Indonesia SMP seKecamatan Brebes terhadap penilaian autentik untuk keterampilan membaca pada kurikulum 2013.

\section{METODE}

\section{Persepsi}

Menurut Philip Kotler (1993) (dalam Riadi, 2012) persepsi adalah proses bagaimana seseorang menyeleksi, mengtur dan menginterpretasikan masukan-masukan informasi untukmenciptakan gambaran keseluruhan yang berarti. Persepsi dapat diartikan sebagai suatu proses kategorisasi dan dan interprestasi yang bersifat selektif. Adapun faktor yang mempengaruhi persepsi seseorang adalah kepribadian orang yang di persepsi dan faktor situasional.

Berbeda dengan pendapat di atas, Robbins (2006) (dalam USU, 2011) menyatakan bahwa "persepsi adalah proses yang digunakan individu mengelola dan menafsirkan kesan indera mereka dalam rangka memberikan makna kepada lingkungan mereka". Meskipun demikian apa yang dipersepsikan seseorang dapat berbeda dari kenyataan yang obyektif. Persepsi ini bisa juga diartikan proses yang dialalui oleh suatu stimulus yang diterima panca indera kemudian diorganisasikan dan diinterprestasikan sehingga individu menyadari yang diinderanya itu. Pendapat tersebut diperkuat oleh Atkinson dan Hilgard (dalam USU, 2011) menyatakan bahwa "persepsi adalah proses dimana kita menafsirkan dan mengorganisasikan pola stimulus dalam lingkungan ". Jadi persepsi timbul karena adanya respon terhadap stimulus. Stimulus yang diterima seseorang sangat komplek, stimulus masuk ke otak, kemudian diartikan, ditafsirkan serta diberi makna melalui proses yang rumit baru dihasilkan persepsi.

Menurut Young (1956) (dalam perdana, 2013) menyatakan bahwa persepsi pada hakikatnya adalah merupakan proses penilaian seseorang terhadap obyek tertentu. Maka persepsi merupakan aktivitas mengindera, mengintegrasikan dan memeberi penilaian pada obyek-obyek fisik maupun obyek sosial. Dan pengindraan tersebut tergantung pada stimulus fisik dan stimulus sosial yang ada di lingkungannya serta hal-hal yang telah dipelajari sebelumnya berupa harapan, nilai-nilai, sikap, ingatan dan lainlain. Wagito(1981) (dalam perdana, 2013) menyatakan bahwa persepsi merupakan proses psikologis dan hasil dari penginderaan serta proses terakhir dari kesadaran sehingga membentuk proses berfikir.

Berdasarkan pendapat para ahli tersebut, maka dapat disimpulkan bahwa persepsi suatu tanggapan atau penerimaan langsung dari sesuatu, proses seseorang mengetahui beberapa hal melalui panca indera.

\section{Penilaian}

Istilah Penilaian pada dasarnya merujuk kepada suatu kegiatan yang dimaksud untuk mengambil keuputusan dalam rangka memberikan nilai terhadap sesuatu (orang, benda, fakta). Keputusan penilaian mungkin 
Ratih Nur Eva Sari, Sukirno

Persepsi Guru Bahasa Indonesia SMP Negeri Se-Kecamatan Brebes Terhadap Penilaian Autentik untuk

Keterampilan Membaca pada Kurikulum 2013

dituangkan dalam batasan-batasan: baik-buruk, memuaskan-tidak memuaskan, berhasil-gagal dan sejenisnya. Dalam konteks pengajaran, penilaian dapat diartikan sebagai suatu proses yang sistematik dalam menentukan tingkat pencapaian tujuan instruksional yang diraih oleh siswa (Wahyuni, dkk, 2006:3). Sementara Sumarna Surapranata mengartikan penilaian juga digunakan untuk mengetahui kekuatan dan kelemahan yang ada dalam proses pembelajaran, sehingga dapat dijadikan dasar untuk pengambilan keputusan (Surapranata, 2004: 1).

Pengertian serupa juga dikemukakan oleh Kerry \& David.Menurut Kerry \& David, "Assessment is the ongoing task of finding out about student's beliefs, strategies, strengths and weaknesses in relation to their learning"( Kerry \& David, 2011:12). Penilaian adalah kegiatan yang sedang berlangsung untuk menemukan pengetahuan tentang strategi, kekuatan dan kelemahan tentang siswa dalam kaitannya dengan belajar mereka.Pengertian lain mengenai penilaian dikemukakan oleh Sudaryono. Ia mengartikan penilaian sebagai salah satu kegiatan yang dilakukan untuk mengukur dan menilai tingkat pencapaian kurikulum dan berhasil tidaknya proses pembelajaran (Sudaryono, 2012: 72).

Menurut E. Mulyasa (2013: 137). secara lebih jelas menyatakan bahwa, Penilaian adalah kegiatan yang dilakukan secara terus menerus untuk mengetahui dan memantau perubahan serta kemajuan yang dicapai peserta didik, maupun untuk memberi skor, angka, atau nilai yang biasa dilakukan dalam penilaian hasil belajar.

Dari beberapa pengertian tentang penilaian tersebut, dapat ditarik kesimpulan bahwa penilaian adalah suatu proses yang sistematik untuk memperolehberbagai informasi secara berkala, berkesinambungan, dan menyeluruh tentang kekuatan dan kelemahan tentang siswa dalam kaitannya dengan proses dan hasil belajar siswa sehingga dapat dijadikan dasar untuk pengambilan keputusan. Dengan penilaian hasil belajar siswa dapat diketahui seberapa besar keberhasilan peserta didik telah menguasai kompetensi atau materi yang telah diajarkan oleh guru. Melalui penilaian juga dapat dijadikan acuan untuk melihat tingkat keberhasilan atau efektivitas guru dalam pembelajaran. Dengan demikian penilaian yang baik akan memberikan informasi yang bermanfaat dalam perbaikan kualitas proses belajar mengajar.

\section{Penilaian Autentik}

Penilaian autentik (authentic assessment) adalah bentuk penilaian yang meminta peserta didik menunjukkan kinerja dalam konteks dunia nyata yang menunjukkan aplikasi bermakna dari penerapan pengetahuan dan keterampilan (Mueller, 2013). Sementara Nurgiyantoro (2011: 23) menyebutkan bahwa penelian autentik merupakan penilaian terhadap tugas-tugas yang menyerupai kegiatan membaca dan menulis sebagai mana halnya di dunia nyata dan disekolah. Tujuannya adalah untuk mengukur berbagai ketrampilan dalam berbagai konteks yang mencerminkan situasi di dunia nyata di mana ketrampilan-ketrampilan tersebut digunakan.

Penelitian autentik adalah proses pengumpulan berbagai data yang bisa memberikan gambaran perkembangan belajar peserta didik (Abidin, 2012:168). Gambaran perkembangan belajar peserta didik perlu diketahui oleh guru agar bisa memastikan bahwa peserta didik mengalami proses pembelajaran dengan benar. Gambaran tentang kemajuan belajar diperlukan disepanjang proses pembelajaran, sehingga penilaian ini tidak dilakukan diakhir periode saja (akhir semester).

Penilaian autentik merupakan pendekatan penilaian yang melibatkan peserta didik secara realistis dalam menilai prestasi mereka sendiri (Surapranata dan Hatta, 2006 : 71). Prinsip dasar penilaian autentik dalam teori pembelajaran adalah peserta didik harus dapat mendemonstrasikan atau melakukan apa yang mereka ketahui. Penilaian autentik perlu dilakukan karena beberapa hal, yaitu (1) penilaian autentik merupakan penilaian secara langsung terhadap kemampuan dan kompetensi peserta didik, (2) penilaian autentik memberikan kesempatan bagi peserta didik untuk mengkonstruksikan hasil pembelajaran, (3) penilaian autentik mengintegrasikan kegiatan belajar, mengajar, 
Ratih Nur Eva Sari, Sukirno

Persepsi Guru Bahasa Indonesia SMP Negeri Se-Kecamatan Brebes Terhadap Penilaian Autentik untuk

Keterampilan Membaca pada Kurikulum 2013

dan penilaian, dan (4) penilaian autentik memberikan kesempatan kepada peserta didik untuk mendemonstrasikan kemampuan yang beragam (Mueller, 2013).

Penilaian autentik merupakan berbagai bentuk penilaian yang mencerminkan pembelajaran peserta didik, prestasi, motivasi, dan sikap dalam kegiatan yang relevan secara intruksional di dalam kelas ( O’Malley dan Pierce, 1996:4). Bentuk-bentuk penilaian autentik sebenarnya tidak asing bagi guru di Indonesia. Akan tetapi, guru lebih akrab dengan jenis penilaian tradisional. Penilaian tradisional lebih menekankan tagihan penguasaan pengetahuan dengan tes objektif, sedangkan penilaian autentik menekankan pada kinerja yang mencerminkan penguasaan pengetahuan dan ketrampilan (Nurgiyantoro, 2011:26).

\section{Pengertian Membaca}

Membaca adalah suatu proses yang dilakukan serta dipergunakan oleh pembaca untuk memperoleh pesan, yang hendak disampaikan oleh penulis melalui media katakata atau bahasa tulis (Tarigan, 2008: 7). Menurut Sukirno (2015:3) membaca adalah semata-mata mengubah tulisan atau cetakan menjadi serangkaian bunyi yang bermakna, atau menghubungkan kata-kata dalam tulisan dengan makna bahasa lisan. Sedangkan menurut Samniah (2016:2) membaca dapat pula dianggap sebagai suatu proses untuk memahami yang tersirat dalam tersurat, yakni memahami makna yang terkandung di dalam kata-kata yang tertulis. Membaca merupakan kegiatan untuk mendapatkan makna dari apa yang tertulis dalam teks (Iskandar dan Sunendar: 245).

Hal yang sama juga diungkapkan oleh Farida (2008: 2) bahwa membaca pada hakikatnya adalah suatu yang rumit yang yang melibatkan banyak hal, tidak hanya melafalkan tulisan tetapi juga melibatkan aktivitas visual, berpikir, psikolinguistik, dan metakognitif. Jadi dapat disimpulkan bahwa membaca adalah aktivitas memahami, menafsirkan, mengingat, dan menuliskannya kembali berdasarkan analisis pikiran sendiri. Melalui kegiatan membaca didapatkan sejumlah informasi yang dalam keadan tertentu bisa mempengaruhi sikap dan pandanganpandangan tentang perilaku kehidupan.

\section{Tujuan Membaca}

Tarigan (2008:9-10) menyatakan bahwa secara umum membaca pemahaman memiliki tujuan sebagai berikut. Pertama, menemukan ide pokok dari kalimat, paragraf, atau wacana. Kedua, memilih butir-butir penting. Ketiga, mengikuti petunjuk-petunjuk. Keempat, menentukan organisasi bahan bacaan. Kelima, menemukan citra visual dan citra lainnya dari bacaan. Keenam, menarik kesimpulankesimpulan. Ketujuh, menduga makna dan meramalkan dampak-dampak dan kesimpulankesimpulan. Kedelapan, merangkum apa yang telah dibaca. Kesembilan, membedakan fakta dan pendapat. Kesepuluh, memperoleh informasi dari aneka sarana khusus, seperti ensiklopedia, atlas, dan peta. Sedangkan menurut Blanon (dalam Sukirno, 2015:4) membaca mempunyai tujuan yang utama yaitu untuk mencari serta memperoleh informasi baik bentuk maupun isi bacaan, 1) memperoleh kesenangan; 2) mengaitkan informasi baru dengan informasi yang telah diketahui; 3) memperoleh informasi untuk laporan tertulis atau lisan; 4) mempelajari struktur teks bacaan; 5) menjawab pertanyaan; 6) menyempurnakan membaca nyaring; 7) mengonfirmasikan atau menolak prediksi.

Membaca hendaknya mempunyai tujuan karena seseorang yang membaca dengan suatu tujuan cenderung lebih memahami dibandingkan dengan orang yang tidak memiliki tujuan dalam membaca. Tujuan membaca secara umum adalah menangkap maksud orang lain yang tertulis. Hal tersebut akan tercapai jika pembaca mampu mengidentifikasi gagasan utama dalam sumber bacaan yang sedang dibaca. Membaca juga bertujuan memahami dan menghayati makna yang terkandung dalam sebuah bacaan, kemudian menetapkan penilaian serta sikap terhadap gagasan yang dipaparkan oleh penulisnya.

Tujuan utama membaca adalah untuk mencari serta memperoleh informasi, mencakup isi, memahami makna bacaan. Makna, arti erat sekali berhubungan dengan maksud tujuan, atau intensif kita dalam 
Ratih Nur Eva Sari, Sukirno

Persepsi Guru Bahasa Indonesia SMP Negeri Se-Kecamatan Brebes Terhadap Penilaian Autentik untuk

Keterampilan Membaca pada Kurikulum 2013

membaca. Berdasarkan beberapa tujuan membaca tersebut, dapat disimpulkan tujuan membaca adalah untuk menemukan dan memahami makna serta informasi yang tertuang dalam suatu bacaan secara lebih tepat dan kritis.

\section{Aspek-aspek membaca}

Tarigan (2008:12-13) terdapat dua aspek penting dalam membaca yaitu: a) keterampilan yang bersifat mekanis (mechanical skills) yang dapat dianggap berada pada urutn yang lebih rendah (lower order). Aspek ini mencakup: 1) pengenalan bentuk huruf; 2) pengenalan unsur-unsur linguistik (onem/grafem, kata, frase, pola, klausa, kalimat, dan lain-lain); 3) pengenalan hubungan/ korespondensi pola jaan dan bunyi (kemampuan menyuarakan bahan tertulis atau "too barck $t$ print"); 4) kecepatan membaca ketaraf lambat. b) keterampilan yang bersifat pemahaman (comprehension skills) yang dapat dianggap berbeda pada urutan yang lebih tinggi. Aspek ini mencakup: 1) memahami pengertian sederhana (leksikal, gramatikal, retorikal); 2) memahami signifikasi atau makna (maksud dan tujuan pengarang, relevansi/keadaan kebudayaan, dan reaksi pembaca); 3) evaluasi atau penilaian (isi, bentuk); 4) kecepatan membaca yang fleksibel, yang mudah disesuaikan dengan keadaan.

\section{Jenis-Jenis Membaca}

Tarigan (2008:23-38) berpendapat bahwa membaca sebagai suatu aktivitas yang kompleks, mempunyai tujuan yang kompleks dan lima masalah yaitu: (1) membaca teliti yaitu membaca yang penekannya diarahkan pada keterampilan memahami dan menguasai isi bacaan, (2) membaca pemahaman yaitu membaca yang penekannya diarahkan pada keterampilan memahami dan menguasai isi bacaan, (3) membaca ide yaitu membaca dengan maksud mencari, memperoleh serta memanfaatkan ide-ide yang tedapat pada bacaan, (4) membaca kritis yaitu membaca yang dilakukan secara bijaksana, penuh tegang hati, mendalam, evaluatif, serta analitis, bukan hanya mencari kesalahan, dan (5) membaca telaah bahasa.
Metode artikel ini ditulis berdasarkan penelitian yang menggunakan pendekatan deskriptif kuantitatif. Menurut Sukmadinata (2017:72) penelitian deskriptif ditujukan untuk mendeskripsikan atau menggambarkan fenomena-fenomena yang ada, baik fenomena yang bersifat alamiah ataupun rekayasa manusia. Penelitian kuantitatif didasari oleh filsafat positivisme yang menekankan fenomena-fenomena objektif dan dikaji secara kuantitatif (Sukmadinata, 2017:53).

Penelitian yang berjudul "Persepsi Guru Bahasa Indonesia SMP Se- Kecamatan Brebes Terhadap Penilaian Autentik untuk Keterampilan Membaca Pada Kurikulum 2013" ini merupakan jenis penelitian deskriptif kuantitatif. Penelitian ini bertujuan untuk mendeskripsikan persepsi guru Bahasa Indonesia terhadap keterampilan membaca di SMP Negeri se-Kecamatan Brebes. Berdasarkan data yang bersifat kuantitatif yakni skor mengenai tingkat persepsi guru Bahasa Indonesia terhadap keterampilan membaca, kemudian diperoleh nilai reratanya dan dikategorikan ke dalam persepsi sangat baik, baik, kurang baik, dan buruk.

Teknik pengumpulan data dalam penelitian ini, dilakukan menggunakan angketatau kuesioner online. Pengisian angket atau kuesioner online melalui google forms dapat diakses melalui link yang sudah dipersiapkan oleh peneliti. Pada link yang sudah dipersiapkan peneliti, terdapat kuesioner mengenai persepsi guru bahasa Indonesia SMP se- kecamatan Brebes terhadap penelitian autentik dalam keterampilan membaca pada Kurikulum 2013 dalam bentuk kuesioner tertutup. Kuesioner tertutup yaitu kuesioner yang diisi dengan cara menceklis $(\sqrt{ })$ pada kolom pilihan jawaban yang sudah tersedia sesuai dengan petunjuk.

\section{HASIL DAN PEMBAHASAN}

Penelitian autentik adalah bentuk penilaian yang meminta peserta didik menunjukkan kinerja seperti yang dilakukan dalam dunia nyata secara bermakna yang merupakan penerapan pengetahuan dan keterampilan yang dimiliki. Prinsip dasar penilaian autentik adalah peserta didik harus 
Ratih Nur Eva Sari, Sukirno

Persepsi Guru Bahasa Indonesia SMP Negeri Se-Kecamatan Brebes Terhadap Penilaian Autentik untuk

Keterampilan Membaca pada Kurikulum 2013

mendemonstrasikan atau melakukan apa yang mereka pelajari. Penelitian autentik merupakan salah satu bentuk penilaian yang disarankan dan menjadi penilaian yang wajib dilaksanakan dalam kurikulum 2013. Saat ini, guru seharusnya sudah memahami konsep penilaian autentik dalam pembelajaran di sekolah.

Hasil penelitian yang diperoleh dengan angket menunjukkan bahwa semua guru mata pelajaran Bahasa Indonesia di SMP Negeri SeKecamatan Brebes telah melaksanakan penilaian autentik dalam pembelajaran. Akan tetapi pelaksanaan tersebut belum sepenuhnya dilakukan dengan baik. Salah satu faktor yang menyebabkan hal tersebut adalah masih terdapat guru yang belum memahami konsep penilaian autentik. Sementara itu, hasil penelitian ini menunjukkan bahwa hanya sebagian kecil saja guru yang belum memahami konsep penilaiain autentik dengan baik.Berdasarkan hasil analisis data di atas, di ketahui bahwa persepsi guru terhadap penilaian autentik dalam pembelajaran membaca di SMP Negeri Se- kecamatan Brebes memiliki mean sebesar 152,65 , range sebesar 46, standar deviation sebesar 10,820, dan variance sebesar 117.082.

Hal ini menunjukkan bahwa guru-guru Bahasa Indonesia di SMP Negeri seKecamatan Brebes memiliki persepsi baik terhadap penilaian autentik dalam pembelajaran membaca. Persepsi baik oleh guru bahasa indonesia diwujudkan dengan mendukung dalam penilaian autentik. Sebagaimana yang sudah dijelaskan di atas dari hasil penghitungan statistik tersebut, dapat diketahui bahwa sebagian besar (75\%) guru Bahasa Indonesia di SMP Negeri seKecamatan Brebes memiliki persepsi yang positif terhadap penilaian autentik. Dibuktikan dengan persepsi yang termasuk dalam kategori positif ini, diketahui bahwa terdapat 3 guru yang dapat dikategorikan memiliki persepsi yang tinggi terhadap informasi mengenai penilaian autentik dalam pembelajaran membaca. Sementara sebanyak 15 guru memiliki persepsi yang termasuk dalam kategori sedang terhadap informasi yang berkaitan dengan penilaian autentik dalam pembelajaran membaca, dan yang terakhir sebanyak 2 guru memiliki persepsi yang termasuk dalam kategori rendah terhadap informasi mengenai penilaian autentik dalam pembelajaran membaca.

\section{Penyerapan guru terhadap penilaian autentik untuk pembelajaran membaca di SMP Negeri Se- kecamatan Brebes}

Berdasarkan tabel distribusi frekuensi skor penyerapan (skor item no 1-16) yang telah dipaparkan pada bagian hasil penelitian, skor yang diperoleh dikategorikan ke dalam kelas tinggi, sedang, rendah. Dari tabel dan gambar di atas, dapat diketahui bahwa terdapat 3 guru yang dapat dikategorikan memiliki penyerapan yang tinggi terhadap informasi mengenai penilaian autentik dalam pembelajaran dalam pembelajaran membaca. Sementara 14 guru memiliki penyerapan yang termasuk dalamkategori sedang terhadap informasi yang berkaitan dengan penilaian autentik dalam pembelajaran membaca. Dan yang terakhir ada 3 guru lainnya memiliki penyerapan yang termasuk dalam kategori rendah terhadap informasi yang berkaitan dengan penilaian autentik dalam pembelajaran membaca, hal ini dikarenakan kurang pahamnya guru mengenai konsep penilaian autentik.

\section{Pemahaman guru terhadap penilaian autentik untuk pembelajaran membaca di SMP Negeri Se- kecamatan Brebes}

Indikator yang kedua adalah pemahaman guru terhadap penilaian autentik dalam pembelajaran membaca. Indikator pemahaman merupakan indikator yang digunakan untuk mengukur tingkat pemahaman guru Bahasa Indonesia terhadap aspek yang berkaitan dengan penilaian autentik dalam pembelajaran membaca. Ada 17 item pertanyaan yang dimaksudkan mengungkap pemahaman guru terhadap penilaian autentik. Dari skor yang diperoleh di lapang, pemahaman guru terhadap penilaian autentik dapat diketahui bahwa dari 20 guru, terdapat 3 guru yang termasuk dalam kategori memiliki pemahaman yang tinggi 9 (baik) terhadap penilaian autentik dalam pembelajaran membaca, 13 guru memiliki pemahaman yang sedang (cukup baik) 
Ratih Nur Eva Sari, Sukirno

Persepsi Guru Bahasa Indonesia SMP Negeri Se-Kecamatan Brebes Terhadap Penilaian Autentik untuk

Keterampilan Membaca pada Kurikulum 2013

terhadap penilaian autentik pada pembelajaran membaca, sementara itu, 4 guru memiliki pemahaman yang rendah (kurang) terhadap penilaian autentik pada pembelajaran membaca.

Bila dibandingkan dengan indikator penyerapan, skor indikator pemahaman guru terhadap penilaian autentik mengalami penurunan sebesar 5\%. Tidak semua guru yang menyerap informasi mengenai penilaian autentik dengan baik dapat memahami penilaian autentik dengan baik pula. Ada 3 guru yang memiliki tingkat penyerapan tinggi dan ada 14 guru yang memiliki penyerapan sedang tetapi memiliki tingkat pemahaman yang rendah terhadap penilaian autentik. Sementara itu, ada 3 guru yang memiliki penyerapan yang berkategori rendah tetapi memahami penilaian autentik dengan baik.

\section{Penilaian guru terhadap penilaian autentik untuk pembelajaran membaca di SMP Negeri Se- kecamatan Brebes}

Indikator yang ketiga adalah penilaian guru terhadap diberlakunya penilaian autentik dalam pembelajaran membaca. Skor perolehan item-item penilaian sebagaimana yang telah disampaikan dalam bagian sebelumnya.Sebanyak $20 \%$ dengan jumlah 4 guru memiliki penilaian tinggi (baik) terhadap penilaian autentik sementara itu, dapat diketahui pula guru yang memperoleh presentase sedang yaitu 14 guru dengan frekuensi $70 \%$, sedangkan guru yang tergolong dalam kategori rendah ada 2 orang dengan frekuensi $10 \%$. Dengan demikian, hanya ada 4 guru yang memiliki penilaiain tinggi terhadap penilaian autentik, selebihnya biasa-biasa saja sehingga dapat dikatakan netral terhadap penilaian autentik. Penilaian yang netral ini menunjukkan guru-guru tidak memilih secara subjektif dan tidak berpihak kepada salah satu jenis penilaian (baik tradisional maupun autentik).

Selain itu ada guru yang dikategorikan rendah dikarena guru tersebut kesulitan dalam penerapan penilaiain autentik.Penyerapan, pemahaman dan penilaian merupakan proses yang berkesinambungan dalam membentuk persersi. Dari hasil analisis ketiga indikator di atas, diketahui bahwa pada tahap awal ( yakni indikator penyerapan). Sebanyak $15 \%$ (3 guru) memiliki penyerapan terhadap informasi tentang penilaian autentik yang berada pada kategori tinggi, $70 \%$ (14 guru) memiliki penyerapan terhadap informasi tentang penilaian autentik dalam pembelajaran membaca yang berada pada kategori sedang, sementara itu, $15 \%$ (3 guru) memiliki penyerapan terhadap informasi tentang penilaian autentik dalam pembelajaran membaca yang berada pada kategori rendah. Jumlah tersebut menurun pada indikator pemahaman yakni hanya sebanyak $15 \%$ (3 guru) memiliki pemahaman terhadap informasi tentang penilaian autentik yang berada pada kategori tinggi, 65\% (13 guru) memiliki pemahaman terhadap informasi tentang penilaian autentik dalam pembelajaran membaca yang berada pada kategori sedang, sementara itu, 20\% (4 guru) memiliki penyerapan terhadap informasi tentang penilaian autentik dalam pembelajaran membaca yang berada pada kategori rendah. Pada indikator ketiga, yakni penilaian oleh guru terhadap penilaian autentik, jumlah guru yang berada di kategori tinggi mengalami kenaikan sebesar 5\% yakni 20\% (4 guru) memiliki penilaian terhadap informasi tentang penilaian autentik yang berada pada kategori tinggi, $70 \%$ (14 guru) memiliki penilaian terhadap informasi tentang penilaian autentik dalam pembelajaran membaca yang berada pada kategori sedang, sementara itu, 10\% (2 guru) memiliki penilaian terhadap informasi tentang penilaian autentik dalam pembelajaran membaca yang berada pada kategori rendah. Berikut ini adalah tabel perbandingan tiap indikator persepsi guru terhadap penilaian autentik dalam pembelajaran membaca di SMP Negeri Se-kecamatan Brebes. 
Ratih Nur Eva Sari, Sukirno

Persepsi Guru Bahasa Indonesia SMP Negeri Se-Kecamatan Brebes Terhadap Penilaian Autentik untuk Keterampilan Membaca pada Kurikulum 2013

Tabel 1. Perbandingan kategori persepsi guru terhadap penilaian autentik untuk pembelajaran membaca di SMP Negeri SeKecamatan Brebes

\begin{tabular}{|l|l|l|l|}
\hline \multirow{2}{*}{ Indikator } & \multicolumn{3}{|l|}{ Kategori } \\
\cline { 2 - 4 } & Tinggi & Sedang & Rendah \\
\hline Persepsi & $15 \%$ & $75 \%$ & $10 \%$ \\
\hline Penyerapan & $15 \%$ & $70 \%$ & $15 \%$ \\
\hline Pemahaman & $15 \%$ & $65 \%$ & $20 \%$ \\
\hline Penilaian & $20 \%$ & $70 \%$ & $10 \%$ \\
\hline
\end{tabular}

Dari tabel di atas, dapat diketahui bahwa tingkat penyerapan, pemahaman, dan penilaian berada pada tingkatan presentase yang berbeda. Guru-guru Bahasa Indonesia SMP Negeri Se- Kecamatan Brebes sudah memiliki penyerapan yang tidak terlalu tinggi dan tidak terlalu rendah terhadap informasiinformasi yang berkaitan dengan penilaian autentik. Tidak hanya itu, guru-guru tersebut juga memiliki tingkat pemahaman sebanyak $15 \%$ dari populasi memiliki pemahaman yang masuk dalam kategori tinggi, 65\% memiliki pemahaman sedang, dan $20 \%$ memiliki pemahaman rendah. Kemudian, sebanyak $70 \%$ guru menilai penilaian autentik dengan biasabiasa saja (tidak terlalu baik dan tidak terlalu buruk) tetapi pada kategori penilaian memiliki peningkatan. Ada $20 \%$ populasi yang menilai dengan baik, dan setelah dianalisis, guru-guru yang memiliki penilaian yang baik terhadap penilaian autentik ternyata berasal dari sekolah yang dapat dikatakan sebagai sekolah favorit.

Selain pengkategorian, dilakukan pula analisis terhadap kategori pada tiap indikator dengan membandingkannya dengan kategori pada persepsi. Hasilnya, ditemukan bahwa ada 3 responden yang memiliki penyerapan tinggi memiliki persepsi yang termasuk tinggi pula. Sementara itu, ditemukan bahwa ada 3 responden yang pemahamannya tinggi terhadap penilaian autentik, dan ditemukan pula 4 responden yang memiliki persepsi yang tinggi pula terhadap penilaian autentik dalam pembelajaranmembaca. Hal ini menunjukkan bahwa ada kecenderungan guru yang memiliki pemahaman baik memiliki persepsi yang baik pula terhadap penilaian autentik.

Dari analisis yang dilakukan terhadap tiap item, respon yang paling sering muncul dalam angket adalah pernyataan "Setuju" atau $\mathrm{S}$, sementara yang paling jarang muncul adalah respon "Sangat Tidak Setuju" atau STS. Guru-guru menghindari memilih jawaban yang ekstrim (baik respon "Sangat Setuju" maupun respon "Sangat Tidak Setuju"). Secara keseluruhan, hanya muncul 9 respon "Sangat Tidak Setuju" terhadap pernyataan yang diajukan.

Selanjutnya, berdasarkan hasil ketegorisasi ketiga indikator yang telah dibahas di bagian sebelumnya, diketahui banyaknya guru yang sudah menerapkan penilaian autentik sebanyak 19 orang (95\%). Oleh karenanya, untuk menjelaskan temuan ini, dilakukan analisis terhadap masing-masing item pertanyaan pada indikator penilaian, yakni mulai item no. 26 sampai item no. 32 .

Pada item yang berbunyi "saya lebih mementingkan penilaian akhir daripada penilaian proses", sebanyak 3 guru (15\%) sangat tidak setuju, sementara 15 guru $(75 \%)$ tidak setuju dengan pendapat tersebut. Sisanya, sebanyak 2 guru (10\%) lebih mementingkan penilaian akhir daripada penilaian proses. Dari perbandingan besaran presentase tersebut, dapat diketahui bahwa sebagian besar guru tidak setuju dengan pendapat penilaian akhir lebih penting daripada penilaian proses.

Dari analisis respon terhadap item penilaian, diketahui pula bahwa sebanyak $25 \%$ (5 guru) setuju dengan pendapat bahwa"Penilaian kinerja (Penilaian alternatif) merupakan penilaian yang bertele-tele". Sebanyak 75\% (15 guru) lainnya tidak setuju dan sangat tidak setuju terhadap pendapat tersebut.

Penilaian yang positif oleh guru terhadap penilaian autentik dikuatkan oleh respon terhadap penilaian autentik. Sejumlah 1 guru $(5 \%)$ sangat setuju dengan pernyataan bahwa "penilaian autentik lebih fair dibanding dengan penilaian tradisional". Sementara itu, sebanyak $75 \%$ (15 guru) setuju dengan pernyataan tersebut dan sebanyak 20\% (4 guru) menyatakan tidak setuju dengan pendapat yang menyatakan bahwa penilaian autentik lebih fair daripada penilaian tradisional. 
Ratih Nur Eva Sari, Sukirno

Persepsi Guru Bahasa Indonesia SMP Negeri Se-Kecamatan Brebes Terhadap Penilaian Autentik untuk

Keterampilan Membaca pada Kurikulum 2013

Dari analisis tiap item, dapat diketahui pula bahwa sebanyak $75 \%$ (15 guru) tidak begitu menyukai penilaian kinerja karena prosedurnya rumit. Sebanyak $40 \% \quad(8$ guru)sangat setuju dengan dan sebanyak $60 \%$ (12 guru) lainnya setuju dengan pernyataan bahwa "Penentuan kriteria penilaian didasarkan pada standar kompetensi dan kompetensi dasar". Dapat diketahui pula pada butir soal nomor 39 bahwa sebanyak 25\% (5 guru) sangat senang meminta siswa mengumpulkan hasil kerja mereka dalam bentuk portofolio, sebanyak $65 \%$ (13 Guru) menyukai dan hanya $10 \%$ ( 2 Guru ) yang tidak setuju meminta siswa mengumpulkan hasil pekerjaan dalam bentuk portofolio.

Selain senang meminta siswa untuk mengumpulkan hasil kerja dalam bentuk portofolio, sebagian besar guru 45\% (9 guru) sangat senang dan sebanyak $45 \%$ (9 guru) senang meminta siswa untuk praktik membaca cerpen, puisi, dan novel dan hanya 10\% (2 guru) yang tidak menyukai meminta siswa untuk praktik membaca cerpen, puisi, dan novel.Meskipun demikian, pada butir soal nomor 12 sebanyak 60\% (12 guru) menilai bahwa penilaian dengan melakukan simulasi membaca nyaring di kelas memerlukan waktu yang lama.

Persepsi positif guru bahasa Indonesia SMP Negeri Se-kecamatan Brebes di perkuat dengan pendapat bahwa Dibanding dengan penilaian tradisional, penilaian kinerja lebih fair ( sebanyak 15\% (3 guru) sangat setuju, 65\% (13 guru) setuju dengan pendapat tersebut).Selain itu, guru Bahasa Indonesia SMPNegeri Se-Kecamatan Brebes tidak menyukai tes pilihan ganda tiap menyelesaikan pembelajaran per standar kompetensi sebanyak ( $60 \%$ ).

Dari uraian di atas, dapat diketahui bahwa pada poin soal nomor 49 sekalipun presentase guru yang menilai penilaian autentik dengan baik hanya sebanyak $80 \%$, guru Bahasa Indonesia SMP Negeri yang berada di Kecamatan Brebes memiliki persepsi yang positif terhadap penilaian autentik. Guruguru Bahasa Indonesia sudah tidak lagi menilai dengan cara tradisional dan cenderung membuka diri terhadap model penilaian yang lain. Tidak hanya terpaku pada penilaian tradisional atau tes saja.

Guru Bahasa Indonesia sudah mengenal penilaian autentik, memahami cara kerja penilaian autentik, bahkan telah memberikan judgement terhadap penilaian autentik tersebut. Peningkatan yang positif ini merupakan indikasi keterbukaan guru Bahasa Indonesia di Kecamatan Brebes terhadap berbagai pengembangan dalam pembelajaran, khususnya dalam hal penilaian pembelajaran membaca.

Persepsi yang timbul dipengaruhi oleh beberapa hal, di antaranya motivasi, ekspetasi atau pengharapan, emosi dan budaya sebagaimana yang disampaikan pada bagian sebelumnya. Dari keempat faktor tersebut, pada penelitian ini, faktor budaya merupakan faktor yang dapat ditelusuri dengan melihat asal sekolah serta masa kerja guru-guru Bahasa Indonesia di SMP Negeri SeKecematan Brebes.

Sekolah ikut berperan dalam membentuk budaya guru. Pada sekolah yang mengembangkan pembelajaran dengan pendekatan student center, penilaian pembelajaran umumnya tidak hanya berupa tes tradisional saja, tetapi juga penilaian kinerja seperti portofolio, proyek, dan sebagainya. Guru-guru pada sekolah yang demikian secara tidak langsung dan lambat laun akan memiliki persepsi yang baik terhadap penilaian autentik. Pada penelitian ini, guru-guru yang berkategori tinggi berasal dari SMP Negeri 2 Brebes, SMP Negeri 1 Brebes, dan SMP Negeri 3 Brebes.

Berkaitan dengan faktor-faktor pembentuk persepsi tersebut, untuk mengubah persepsi guru terhadap penilaian autentik dalam pembelajaran dapat dilakukan dengan beberapa cara. Salah satunya dengan mengubah budaya pembelajaran Bahasa Indonesia, termasuk mengubah budaya penilaian yang masih tradisional dengan mengombinasikannya dengan penilaian autentik. Budaya belajar (termasuk model penilaian yang dilakukan oleh guru) dapat mempengaruhi motivasi siswa. Salah satunya, penilain autentik yang dilakukan secara transparan dapat memudahkan identifikasi kemampuan siswa, sehingga siswa mengerti 
Ratih Nur Eva Sari, Sukirno

Persepsi Guru Bahasa Indonesia SMP Negeri Se-Kecamatan Brebes Terhadap Penilaian Autentik untuk Keterampilan Membaca pada Kurikulum 2013

hal-hal apa saja yang kurang dikuasai dan perlu untuk ditingkatkan.

Hasil persepsi yang baik mengenai penilaian autentik ini bukan berarti semua guru Bahasa Indonesia menerapkan penilaian autentik setiap melakukan penilaian. Persepsi yang baik juga tidak berarti guru-guru Bahasa Indonesia sudah mahir dalam melakukan penilaian autentik. Meskipun demikian, persepsi yang baik ini dapat dijadikan modal awal untuk penerapan penilaian autentik dalam pembelajaran. Dengan tanggapan yang baik mengenai penilaian autentik, diharapkan guruguru bersedia menerapkan penilaian autentik dalam pembelajaran. Penerapan tersebut secara tidak langsung akan ikut serta meningkatkan kemampuan siswa dalam pembelajaran membaca pada mapel Bahasa Indonesia.

\section{KESIMPULAN}

Berdasarkan hasil analisis data guru Bahasa Indonesia di SMP Negeri seKecamatan Brebes diketahui Sebanyak 15\% memiliki persepsi yang tinggi terhadap penilaian autentik dalam pembelajaran membaca. Sebanyak $75 \%$ lainnya memiliki persepsi yang sedang terhadap penilaian autentik dan dapat diketahui pula sebanyak $10 \%$ lainnya memiliki persepsi rendah terhadap penilaian autentik dalam pembelajaran membaca pada mata pelajaran Bahasa Indonesia. Persepsi guru Bahasa Indonesia di SMP Negeri seKecamatan Brebes terhadap penilaian autentik dalam pembelajaran Bahasa Indonesia dapat dilihat setidaknya dari tiga indikator yaitu indikator penyerapan, pemahaman dan penilaian. Setelah dianalisis dan dilakukan pengkategorian, didapat hasil bahwa sebanyak $15 \%$ guru memiliki penyerapan yang tinggi, $70 \%$ guru memiliki penyerapan sedang, $15 \%$ guru memiliki penyerapan rendah terhadap informasi mengenai penilaian autentik, sebanyak $15 \%$ guru memiliki pemahaman yang tinggi $65 \%$ guru memiliki pemahaman sedang, $20 \%$ guru memiliki pemahaman rendah terhadap penilaian autentik, sementara sebanyak 20\% guru memiliki penilaian yang tinggi $70 \%$ guru memiliki penilaian sedang, $10 \%$ guru memiliki penilaian rendah terhadap penilaian autentik. Semua hasil rata-rata indikator tersebut berada pada kategori baik. Oleh karena itu, dapat diambil kesimpulan bahwa persepsi guru Bahasa Indonesia terhadap penilaian autentik dalam keterampilan membaca di SMP Negeri se-Kecamatan Brebes adalah baik.

\section{DAFTAR PUSTAKA}

Abidin, Yunus. 2012. Pembelajaran Bahasa Berbasis Pendidikan Karakter. Bandung: PT Refika Aditama.

Iskandarwassid dan Sunendar, D. 2008.Strategi Pembelajaran Bahasa. Bandung: Rosda.

Mueller, Jon. 2013. Authentic Assesment Toolbax. North Central College. http://ifmueller.faculty.noctrl.edu/too lbox/index.htm. diunduh pada 4 April 2020.

Mulyasa.2013. Pengembangan dan Implementasi Kurikulum 2013. Bandung: PT Remaja Rosdakarya.

Nurgiyantoro, Burhan. 2011. Penilaian Otentik (dalam Pembelajaran Bahasa). Yogyakarta: Gadjah Mada University Press.

O'Malley, J. Michael dan Lorraine Valdez Pierce. 1996. Authentic Assessment for English Language Learners: Practical Approaches for Teacher. Boston: Addison-Wesley Publishing Company.

Perdana, Andrean. 2013. Pengertian dan Proses Persepsi Manusia. http://www. Yuwonoputra.om/2013/06/pengertian-danproses-persepsi-manusia.html, diunduh pada 4 April 2020.

Riadi.2012. teori Persepsi. http:// www.kajianpustaka.com/2012/10/teo ri-pengertian-proses-faktorpersepsi.html, diunduh pada 4 April 2020. 
Ratih Nur Eva Sari, Sukirno

Persepsi Guru Bahasa Indonesia SMP Negeri Se-Kecamatan Brebes Terhadap Penilaian Autentik untuk Keterampilan Membaca pada Kurikulum 2013

Sudaryono. 2012. Dasar-dasar Evaluasi Pembelajaran. Yogyakarta.: Graha Ilmu.

Sukirno. 2015. Membaca Pemahaman Yang Efektif. Yogyakarta: Pustaka Pelajar.

Sukmadinata, Nana Syaodih 2017. Metode Penelitian Pendidikan. Bandung: PT Remaja Rosdakarya Offset.

Surapranata dan Mohammad Hatta. 2006. Penilaian Portofolio. Bandung: PT Remaja Rodakarya.

Tarigan, Henry Guntur. 2008. Membaca Sebagai Suatu Keterampilan Berbahasa. Bandung: Angkasa.

Universitas Sumatera Utara. 2011. Tinjauan Pustaka. Repository. usu.ac.id 